\title{
Discurso del Presidente de la Asociación Argentina de Cirugía Asociación Argentina de Cirugía Presidential Address
}

\author{
Roberto A. Cerutti*
}

Felicito al Dr. Enrique Ortiz y al Comité Científico por la organización y nivel académico alcanzado en este $90^{\circ}$ Congreso Argentino de Cirugía.

Quiero, como presidente de la Asociación Argentina de Cirugía (AAC) en el próximo período 2020, hacer algunas consideraciones y esbozar los lineamientos por desarrollar.

Como primer gesto quiero enfáticamente destacar la figura del Dr. Juan Álvarez Rodríguez, a quien sucedo en el cargo y con quien he compartido las tareas de Comisión Directiva (CD). Pude conocer durante la gestión a una persona con gran capacidad de trabajo, honestidad intelectual y compromiso.

Gracias, Juan, por tu valioso aporte a la AAC durante tu gestión y por tu amistad.

Al inicio de año, la AAC presentaba en su contexto institucional algunas realidades para tener en cuenta : a) una base societaria estable, b) un equilibrio económico-financiero precario, c) demanda de nuevos servicios y d) conflictos con el desarrollo de las subespecialidades quirúrgicas.

En relación con una base societaria estable, el número de socios a lo largo de los últimos 10 años muestra un perfil de estabilidad sin mayores variaciones. No decrece, pero tampoco se observa una tendencia creciente, a pesar del esfuerzo de gestiones previas que intentaron incrementar el número de afiliados. Quizá esto se deba a falta de propuestas atractivas para incorporar un mayor número de MAAC (Miembro de la AAC).

Por otra parte, existen costos fijos, representados fundamentalmente por los sueldos y cargas sociales del personal, gastos en servicios y gastos operativos mensuales. Diversas razones explican este desfase, como la dolarización en el costo del Congreso Anual, el retraso en la actualización de las cuotas societarias, la dificultad para aumentar el valor de los Cursos Anuales y la negociación cada vez más difícil con las empresas que colaboran con el financiamiento del Congreso.

La situación económico-financiera de la AAC es precaria y más aún en un país en crisis.

Con respecto a la demanda de nuevos servicios, los reclamos se refieren a la defensa de los honorarios profesionales, de las condiciones laborales, de los conflictos entre cirujanos e instituciones, e incluso a las posibilidades de inserción laboral. Es necesario involucrarse más profundamente en acciones gremiales que defiendan los intereses profesionales de los cirujanos. En este sentido, se están realizando entrevistas para incorporar a la institución un abogado, con experiencia en temas laborales y gremiales.

Sobre los conflictos con el desarrollo de las subespecialidades quirúrgicas, observamos múltiples actividades científicas a lo largo del año, bajo la forma de Jornadas o Congresos, donde se repiten los temas, se superponen fechas, se convocan similares expositores y se apela a los mismos financiadores de la industria. Esto complica el aporte de las empresas a la Asociación, ya que deben repartir entre diferentes eventos un mismo presupuesto.

Sobre la base de estas observaciones, la Comisión Directiva creyó conveniente buscar un asesoramiento externo, con el objetivo de lograr el fortalecimiento institucional y la sustentabilidad económica que permitan el crecimiento de la AAC. Se decidió convocar a la Consultora Paradigma, que cuenta con una amplia trayectoria en proyectos de desarrollo en diferentes empresas del país.

En el Congreso Argentino de Cirugía participó en un Stand y llevó a cabo una encuesta de opinión.

Desarrolló un trabajo a lo largo de 9 semanas que comenzó a principios de abril con el reconocimiento de la Organización e iniciativas en curso, el análisis de nuestra situación particular y del contexto externo.

A continuación se evaluaron las capacidades críticas de la Asociación y se definieron los principales objetivos y lineamientos estratégicos. Se priorizaron las oportunidades de mejoras y se formalizó un programa de transformación, para finalizar con el esbozo de las dinámicas de gestión y seguimiento.

Además, se realizaron 4 Workshops donde participaron: la Comisión Directiva, Personal estable de la AAC y miembros de los distintos Comités y Comisiones.

Este trabajo conjunto permitió evaluar y delinear objetivos estratégicos y oportunidades de mejora que facilitaron la puesta en marcha de lo que denominamos "Programa de transformación de la AAC".

Se definieron 10 Proyectos de Trabajo:

- Modelo de Red

- Crecimiento de la base de socios

- Acompañamiento gremial

- Actualización de la Organización a nuevos miembros

- Actualización del modelo operativo

- Programa de tutelaje

- Evaluación de las competencias y capacidades del equipo de prensa

- Evaluación del clima organizacional

- Expansión comercial del PSQ (Programa de Simulación Quirúrgica) (productos y servicios)

- Mapeo de grupos de interés para alianzas estratégicas

- Integración de Asociaciones y modalidades de acceso al Congreso 


\section{CRONOGRAMA INICIAL}

Fase Comunicacional y de Priorización de Proyectos

En esta plantilla se describen las actividades de preparación, priorización y comunicación del desarrollo de los proyectos en esta primera fase de gestión, teniendo como fecha de inicio de los 4 primeros proyectos priorizados el 19 de agosto.

- Modelo en RED

- Actualización del modelo operativo

- Programa de tutelaje

- Renovación de los objetivos y necesidades del Equipo de Prensa

\section{MODELO EN RED ¿Cuál es el concepto?}

Se entiende como tal una estructura de relacionamiento de la AAC con todos los grupos de interés de un modo más horizontal. Un sistema de vinculación ágil, no burocrático, participativo, de interacción bilateral y beneficio mutuo.

De ahí la necesidad de un cambio en el modelo de relacionamiento, que, sin perder las individualidades, multiplique las oportunidades de mejora y sea de beneficio multilateral.

\section{Objetivos específicos}

- Definir las entidades con las cuales se quiere articular un modelo de Gestión en Red.

En principio se reconocieron las siguientes: a) Capítulos de la AAC, b) Residencias de Cirugía, c) Sociedades Científicas afines, c) Organismos gubernamentales nacionales, provinciales, municipales, d) Sponsors.

- Reconocer el modo de vinculación más conveniente con cada grupo de interés.

Inicialmente se consideró iniciar con el 10\% de los Capítulos que tienen relación con la AAC y, durante el desarrollo, ir incorporando progresivamente más Capítulos.

El plazo estimado del proyecto es de 12 meses para cubrir la totalidad de los Capítulos. Si bien se inició con unos pocos el desarrollo de estos, se agilizará la integración de más.

\section{ACTUALIZACIÓN DEL MODELO OPERATIVO Cronograma Proyectado}

Cuando hablamos del "modelo operativo", nos referimos fundamentalmente al modelo de funcionamiento actual que tiene la AAC. Si bien es cierto que la Asociación opera tanto internamente, en lo que es su propia estructura organizacional, cuanto externamente en su relación con entidades afines, como Sociedades Quirúrgicas del interior del país y otras Sociedades con intereses comunes, esta actualización debería circunscribirse, al menos inicialmente, a la estructura interna de la Asociación.

¿Cuál fue el objetivo general que se planteó?

Reconvertir y modernizar el modelo de gestión operativa interna de la AAC.

Para ello se definieron objetivos específicos tales como:

- Definir las incumbencias de cada Comité y Comisión.

- Establecer las relaciones jerárquicas entre unos y otros.

- Contar con una agenda anual de trabajo de cada estructura.

\section{PROGRAMA DE TUTELAJE Cronograma Proyectado}

\section{Justificación}

La experiencia no es transferible, pero puede ser una herramienta muy valiosa en la orientación y facilitación de la formación de cirujanos jóvenes.

En este contexto, la Asociación podría ofrecer un servicio extraordinario, como es aprovechar la experiencia y los contactos de nuestros MAAC "senior", para tutelar y facilitar el desarrollo de Residentes de Cirugía en Servicios con programas deficitarios.

¿Cuál es el objetivo principal?

Establecer la conexión entre cirujanos referentes en la especialidad y cirujanos en formación, para orientar y facilitar el desarrollo profesional de estos últimos.

Y también estaremos trabajando con el equipo de prensa.

\section{PROGRAMA DE PRENSA, COMUNICACIÓN Y MARKETING \\ Cronograma Proyectado}

¿Cuál es el objetivo principal?

Si bien la AAC cuenta con asesoría externa referida al área de Prensa, Comunicación y Marketing gracias a la cual logró excelente repercusión en lo que respecta al posicionamiento de la Asociación en la comunidad no médica a través de los medios de comunicación, se propuso fomentar el trabajo de comunicación interna para fortalecer lazos con los comités, comisiones y capítulos. Al mismo tiempo se aumentará la comunicación externa para fortalecer vínculos con los socios y no socios. 
¿Qué es lo que haremos?

Visualizar y difundir las propuestas, actividades, logros y avances que presenten los comités, comisiones y capítulos. Establecer una relación fluida y a largo plazo con cada uno de ellos.

Generar estrategias de comunicación para alentar a la certificación de no socios y continuar con la recertificación de socios.

Aumentar el sentido de pertenencia a la Asociación y trabajar sobre el concepto de federalismo.

Desarrollar la expansión del PSQ como modelo de aprendizaje y simulación en Latinoamérica.

Continuar con el posicionamiento de la Asociación en la comunidad no médica a través de los medios de comunicación para que los voceros y la AAC sigan siendo referentes en distintos temas de interés vinculados a la cirugía.

Es importante considerar la incorporación de proyectos de la cartera ya anteriormente definida para su desarrollo en vista de que dos de ellos están próximos a finalizar (Actualización del modelo operativo y Renovación de los objetivos y necesidades del equipo de prensa).

En futura reunión de la CD será importante la priorización de, al menos, 2 proyectos más para su desarrollo.

En conclusión: la evaluación del contexto de la AAC nos hizo plantear 4 temas principales.

En reunión de la CD se decidió solicitar un asesoramiento externo.

La empresa elegida fue Paradigma, con importante trayectoria en el mercado.

Realizó recopilación de datos durante el Congreso, trabajó 9 semanas, realizó 4 Workshops y presentó junto a la CD el "Programa de transformación de la AAC".
Se generaron 10 proyectos.

Se priorizaron 4 proyectos que se iniciaron el 19/8/19.

\section{PROYECTOS 2020}

En el próximo año 2020 concluiremos estos proyectos iniciados y continuaremos con los restantes.

Tenemos claras intenciones de avanzar en este rumbo, de conformar un grupo homogéneo con ganas de trabajar y aportar.

Mi deseo como Presidente de la AAC es lograr la unidad de los cirujanos, que funcionemos unidos, aportando ideas y con disenso si así lo piensan, pues todos tenemos derecho a pensar diferente.

Trabajemos fuerte para lograr el fortalecimiento institucional de la asociación, que tenga sustentabilidad económica y se logre un crecimiento sostenido.

Para 2020 proyectamos concretar estos proyectos iniciados y agregar los restantes para tratar de darle a la AAC un crecimiento estable.

Todo esto se va a lograr con el trabajo conjunto, trabajo en equipo, participando y aportando todos. Las puertas de la AAC y su comisión directiva están abiertas a las inquietudes que ustedes tengan. Comuníquense con cualquiera de nosotros o acérquense. Es mi deseo más profundo que nos unamos para trabajar todos juntos por nuestra querida AAC.

- Proyecto de Expansión comercial del PSQ (productos y servicios)

- Proyecto de Acompañamiento gremial

- Proyecto de Evaluación de las competencias y capacidades del equipo de prensa

Muchas gracias

\section{- ENGLISH VERSION}

I congratulate Dr. Enrique Ortiz and the Scientific Committee for the organization and academic level reached in this $90^{\text {th }}$ Argentine Congress of Surgery (ACS).

I want, as president of the Asociación Argentina de Cirugía (AAC) in the next 2020 period, to make some considerations and outline the guidelines to be developed.

As a first gesture I want to emphatically highlight the figure of Dr. Juan Álvarez Rodríguez, to whom I follow in office and with whom I have shared the Board of Directors tasks. I was able to meet a person with great work capacity, intellectual honesty and commitment during management.

Thank you, Juan, for your valuable contribution to the AAC during your management and for your friendship.

At the beginning of the year, the AAC presented in its institutional context some realities to take into account: a) a stable corporate base, b) a precarious economic-financial balance, c) demand for new services and d) conflicts with the development of surgical subspecialties.

In relation to a stable corporate base, the number of partners over the past 10 years shows a stable profile without major variations. It does not decrease, but there is also a growing trend, despite previous efforts that tried to increase the number of affiliates. This may be due to the lack of attractive proposals to incorporate a larger number of MAACs (member of AAC). 
On the other hand, there are fixed costs, mainly represented by salaries and social charges of staff, service expenses and monthly operating expenses. Various reasons explain this lag, such as the dollarization in the cost of the Annual Congress, the delay in updating the corporate fees, the difficulty in increasing the value of the Annual Courses and the increasingly difficult negotiation with the companies that collaborate with the Congress financing.

The economic and financial situation of the $A A C$ is precarious and even more so in a country in crisis.

With respect to the demand for new services, the claims refer to the defense of professional fees, working conditions, conflicts between surgeons and institutions, and even the possibilities of job placement. It is necessary to get more deeply involved in union actions that defend the professional interests of surgeons. In this sense, interviews are being conducted to incorporate a lawyer into the institution, with experience in labor and union issues.

Regarding the conflicts with the development of surgical subspecialties, we observe multiple scientific activities throughout the year, in the form of conferences or congresses, where the themes are repeated, dates are superimposed, similar exhibitors are called and the same funders are appealed of the industry. This complicates the contribution of companies to the Association, since they must distribute the same budget between different events.

Based on these observations, the Board of Directors considered it appropriate to seek external advice, with the aim of achieving institutional strengthening and economic sustainability that allow the growth of the AAC. It was decided to convene the Paradigma Consultant, which has extensive experience in development projects in different companies in the country.

In the Argentine Congress of Surgery the company participated in a Stand and carried out an opinion poll.

They developed a work over 9 weeks that began in early April with the recognition of the Organization and ongoing initiatives, the analysis of our particular situation and the external context.

The critical capacities of the Association were then evaluated and the main objectives and strategic guidelines were defined. Opportunities for improvements were prioritized and a transformation program was formalized, to end with the outline of management and monitoring dynamics.

In addition, 4 Workshops were held where they participated: the Board of Directors, AAC stable staff and members of the different Committees and Commissions.

This joint work allowed the evaluation and delineation of strategic objectives and opportunities for improvement that facilitated the implementation of what we call the "AAC transformation program".

10 Work Projects were defined:

- Network Model

- Growth of the partner base

- Guild Accompaniment

- Update of the Organization to new members

- Operating model update

- Guardianship Program

- Evaluation of the skills and capabilities of the press team

- Organizational Climate Assessment

- Commercial expansion of the PSQ (Surgical Simulation Program) (products and services)

- Stakeholder mapping for strategic alliances

- Integration of Associations and modalities of access to Congress

\section{INITIAL SCHEDULE}

\section{Communication and Project Prioritization Phase}

This template describes the activities of preparation, prioritization and communication of project development in this first phase of management, with the start date of the first 4 projects prioritized on August 19.

- Network model

- Operating model update

- Guardianship Program

- Renewal of the objectives and needs of the Press Team

\section{NETWORK MODEL \\ What is the concept?}

It is understood as such a relationship structure of the AAC with all stakeholders in a more horizontal way. An agile, non-bureaucratic, participatory, bilateral interaction and mutual benefit system.

Hence the need for a change in the relationship model, which, without losing individualities, multiplies opportunities for improvement and is of multilateral benefit.

\section{Specific objectives}

- Define the entities with which we want to articulate a Network Management model.

In principle, the following were recognized: a) AAC Chapters, b) Residences of Surgery, c) Related Scientific Societies, c) National, provincial, municipal government agencies, d) Sponsors. 
- Recognize the most convenient way of linking with each interest group.

Initially it was considered to start with $10 \%$ of the Chapters that are related to the AAC and, during development, to gradually incorporate more Chapters.

The estimated term of the project is 12 months to cover all the Chapters. Although the development of these began with a few, the integration of more will be speeded up.

\section{UPDATE OF THE OPERATING MODEL Projected Schedule}

When we talk about the "operating model", we refer fundamentally to the current operating model that the AAC has. While it is true that the Association operates both internally, in what is its own organizational structure, and externally in its relationship with related entities, such as Surgical Societies of the interior of the country and other Societies with common interests, this update should be limited, at least initially, to the internal structure of the Association.

What was the overall objective that was set?

Reconvert and modernize the internal operational management model of the AAC.

For this, specific objectives were defined such as:

Define the responsibilities of each Committee and Commission.

Establish hierarchical relationships between each other.

Have an annual work agenda for each structure.

\section{TUTELAGE PROGRAM \\ Projected Schedule}

\section{Justification}

The experience is not transferable, but it can be a very valuable tool in the orientation and facilitation of the training of young surgeons.

In this context, the Association could offer an extraordinary service, such as taking advantage of the experience and contacts of our "senior" MAACs, to guard and facilitate the development of Residents of Surgery in Services with deficit programs.

\section{What is the main objective?}

Establish the connection between referent surgeons in the specialty and surgeons in training, to guide and facilitate the professional development of the latter.
And we will also be working with the press team.

\section{PRESS, COMMUNICATION AND MARKETING PROGRAM Projected Schedule}

What is the main objective?

Although the AAC has external advice related to the area of Press, Communication and Marketing, thanks to which it achieved an excellent impact regarding the positioning of the Association in the non-medical community through the media, it was proposed to promote Internal communication work to strengthen ties with committees, commissions and chapters. At the same time, external communication will be increased to strengthen links with partners and non-partners.

\section{What will we do?}

Visualize and disseminate the proposals, activities, achievements and advances presented by the committees, commissions and chapters. Establish a fluid and long-term relationship with each of them.

Generate communication strategies to encourage non-member certification and continue recertification of partners.

Increase the sense of belonging to the Association and work on the concept of federalism.

Develop the expansion of the PSQ as a learning and simulation model in Latin America.

Continue with the positioning of the Association in the non-medical community through the media so that the spokespersons and the AAC continue to be references in different topics of interest related to surgery.

It is important to consider the incorporation of projects from the portfolio already defined for its development in view of the fact that two of them are nearing completion (Update of the operational model and Renewal of the objectives and needs of the press team).

In the future meeting of the Board of Directors it will be important to prioritize at least 2 more projects for its development.

In conclusion: the evaluation of the context of the AAC made us raise 4 main themes.

At the Board of Directors meeting it was decided to request external advice.

The company chosen was Paradigma, with important experience in the market.

He collected data during the Congress, worked 9 weeks, held 4 Workshops and presented the "AAC transformation program" with the CD. 
10 projects were generated. prioritized.

Four projects that started on $8 / 19 / 19$ were

\section{PROJECTS}

In the next year 2020 we will conclude these initiated projects and continue with the remaining ones.

We have clear intentions to move forward in this direction, to form a homogeneous group eager to work and contribute.

My desire as President of the AAC is to achieve the unity of surgeons, that we work together, contributing ideas and dissent if they think so, because we all have the right to think differently.

Let's work hard to achieve the institutional strengthening of the association, that has economic sustainability and sustained growth.

By 2020 we plan to specify these initiated AAC and add the remaining ones to try to give the stable growth.

All this will be achieved with joint work, teamwork, participation and contribution by all. The doors of the AAC and its board of directors are open to any concerns you may have. Contact any of us or come closer. It is my deepest desire that we join together to work together for our beloved AAC.

- PSQ Commercial Expansion Project (products and services)

- Guild Accompaniment Project

- Project of Evaluation of the competences and capacities of the press team

Thank you 